\title{
THE ANTIQUITY OF PEARL SHELL (PINCTADA sp.) BURIAL ARTIFACTS IN PALAU, WESTERN MICRONESIA
}

\author{
Scott M Fitzpatrick ${ }^{1}$ Jenna E Boyle \\ Department of Anthropology, University of Oregon, Eugene, Oregon 97403, USA.
}

\begin{abstract}
Pearl shell was an important and highly valued resource for producing tools and ornaments in Oceania. One pearl shell artifact type that is quite rare in Micronesia, however, is the crescent-shaped scraper/grater. These artifacts have recently been found in 2 burial caves in Palau, Western Caroline Islands, suggesting they may have played important social and symbolic roles in society. The first direct accelerator mass spectrometry (AMS) dating of this tool type, found in association with an in-situ female burial at the Chelechol ra Orrak site, provides a date of AD 150-270, while associated dates range from $770 \mathrm{BC}-\mathrm{AD} 180$. These dates help contextualize human burials and associated artifacts from one of the earliest and most diverse burial sites in Austronesia.
\end{abstract}

\section{INTRODUCTION}

Prehistoric peoples in the Pacific used pearl shell (Pinctada sp.) for producing a variety of tools and ornaments over a period of $3000 \mathrm{yr}$ or more. In Melanesia, early Lapita settlers in the Mussau Islands (Kirch 1997:213-4) and late preceramic inhabitants in the northern Solomons (Wickler 2001:200) used whole valves of pearl shell as vegetable or coconut peelers and produced trolling hook shanks (Wickler 2001:199). Pearl shell "crescents", often considered wealth or status items, are also worn today as neck ornaments in parts of New Guinea (Sillitoe 1988:396) and Vanuatu (Speiser 1990:165). Pearl shell is known archaeologically and ethnographically in Polynesia for manufacturing fishhooks (Davidson 1968; Sinoto and McCoy 1974; Emory 1975:199-205; Bellwood 1978; Kirch 1979:176; Walter 1989, 1990; Kirch et al. 1992; Allen 1994), and sometimes harpoon points (Sinoto 1968). In Micronesia, pearl shell was used for making fishhooks (Intoh and Leach 1985:100-4), trolling lures (e.g. Pohnpei, Kosrae, and the Marshall Islands; Ayres 1990:1917; Intoh 1998), and various other objects (Sinoto 1984:36; Intoh and Leach 1985:101; Shun and Athens 1990:236-37; Carucci 1992:94). Pearl shell scraper/graters, similar to ones found outside Micronesia, were also recently recovered in archaeological investigations. All are from Palauan burial caves (Rieth and Liston 2001; Fitzpatrick 2003), but their chronology and function are poorly documented.

With the advent of accelerator mass spectrometry (AMS) radiocarbon dating, archaeologists can now date smaller samples of artifacts with a higher degree of accuracy than using conventional techniques. This is especially crucial in contexts that may be disturbed, contaminated, or have only associated dates (e.g. Rick 2001). In addition, direct dating of artifacts using AMS can refine artifact chronologies with relatively high precision (Vellanoweth 2001).

In this paper, we describe the first direct dating of this tool type at the Chelechol ra Orrak site in Palau using AMS. Our goals include: 1) determining the antiquity of burials and grave goods at the site, and 2) developing a chronology for these important artifacts throughout the Pacific. We first provide a brief background on archaeological research at Chelechol ra Orrak and discuss the provenience and significance of the pearl shell scraper/grater tools found in association with early human burials. Four additional ${ }^{14} \mathrm{C}$ dates from strata that contained the artifacts and human skeletal remains are used to assess the importance of directly dating artifacts in complex cultural deposits.

\footnotetext{
${ }^{1}$ Corresponding author. Email: malthus@ darkwing.uoregon.edu.
} 


\section{BACKGROUND}

Palau is located in the Western Caroline Islands of Micronesia approximately $600 \mathrm{~km}$ equidistant from the Philippines to the west and New Guinea to the south. Recent archaeological investigations indicate that the archipelago was probably settled by at least 1000-1400 BC (Liston et al. 1998; Wickler 2001; Fitzpatrick 2002a), although paleoenvironmental data suggest that colonization could have occurred even earlier (Athens and Ward 2001). Despite the increase in archaeological research in Palau, and especially on the large volcanic island of Babeldaob, dated contexts that extend past 500 BC are rare (Wickler 2001; Fitzpatrick 2003).

The Chelechol ra Orrak ("beach of Orrak") site is located along the western fringe of Orrak, a small "Rock Island" approximately $1 \mathrm{~km}$ east of Babeldaob's southeastern tip (Figure 1). This raised limestone island has rough karst topography and numerous caves and rockshelters. Blaiyok (1993) originally identified the site as a stone money quarry used within the last few hundred yr by Yapese Islanders (Fitzpatrick 2001, 2002b). Earlier cultural deposits ( 1000 yr BC) were discovered at the site during recent excavations and produced the pearl shell artifacts discussed here (Fitzpatrick 2002a, 2003).

Human remains were found in all 4 test units in stratified deposits usually deeper than $60 \mathrm{~cm}$. Preliminary osteological analysis by Nelson et al. (2002) indicates that at least 25 individuals were buried in the cave, 14 of which were recovered in Test Unit 1. Human remains include neonates, prenates, adolescents, and adults of both sexes, comprising one of the largest, earliest, and most diverse burial assemblages in the Pacific Islands.

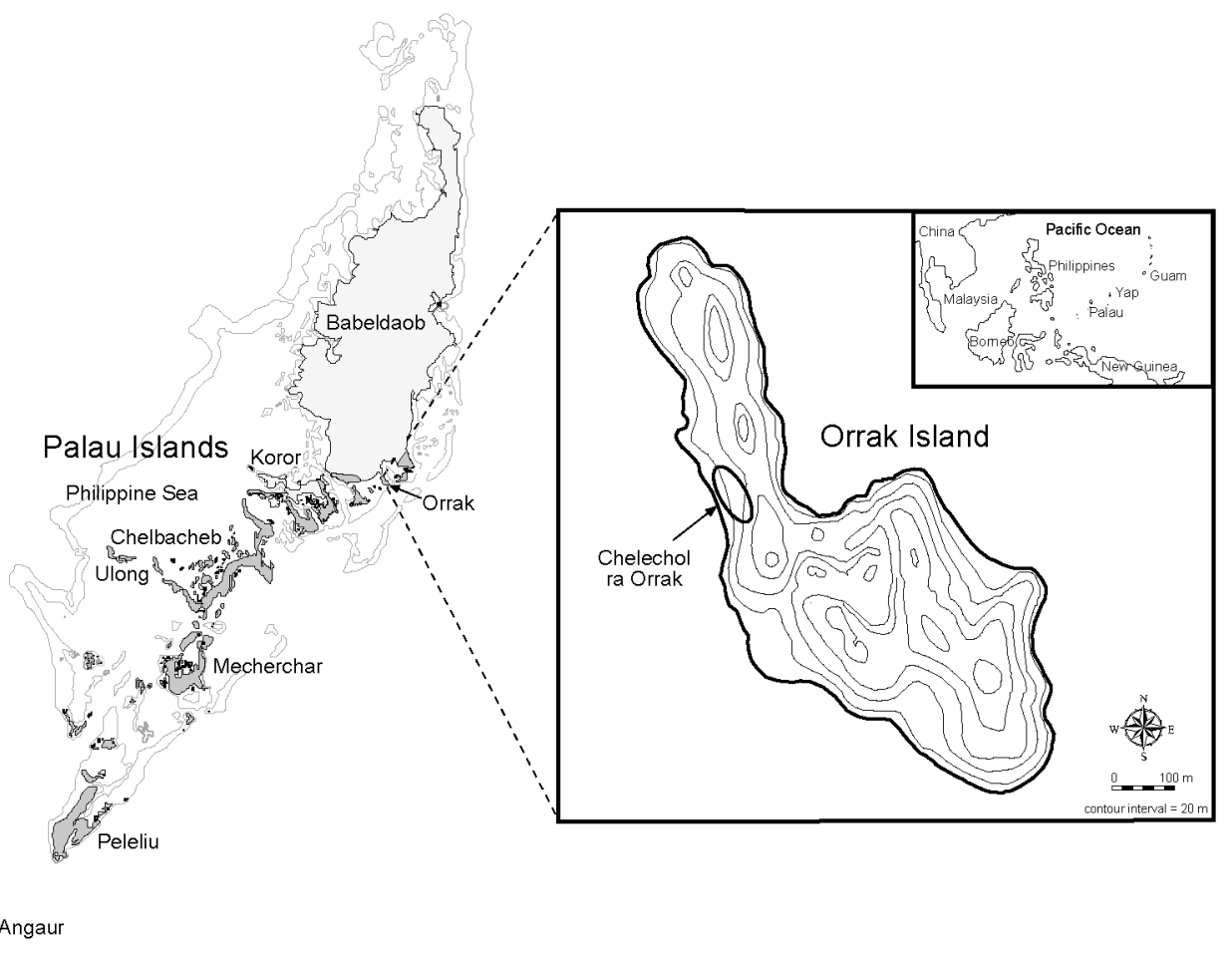

Figure 1 Map of main Palauan archipelago with Orrak Island inset 
Due to the sandy nature of the deeper deposits and the likelihood that burial activity took place over at least a 1000-yr period (with later burials disturbing earlier ones; Fitzpatrick 2003), the skeletal assemblage was highly fragmented and rather poorly preserved. However, 2 undisturbed in-situ burials were discovered a meter deep in Test Unit 1. Three pearl shell scraper/graters were located directly above the left femur of a supine female burial in Layer 9 and are the only definitive burial goods discovered at the site. Two other fragments of similar tools were also found in Test Unit 1 (Layer 7) and one in Test Unit 2 (Layer 5; Table 1).

A variety of artifacts such as unworked marine shell, shell ornaments, shark teeth, bone tools, and ceramic vessels have been reported from burial sites in Palau (Beardsley 1998; Liston et al. 1998; Rieth and Liston 2001), but only Ngermereues Ridge and Chelechol ra Orrak have produced pearl shell artifacts. To determine the antiquity of these artifacts and their associated burial contexts in Test Unit 1, 5 samples, including a small piece from a pearl shell scraper/grater tool were submitted for AMS ${ }^{14} \mathrm{C}$ dating. ${ }^{2}$

Table 1 Pearl shell scraper/grater artifacts from Chelechol ra Orrak

\begin{tabular}{ccccccc}
\hline TU & Layer & cmbs & $\begin{array}{c}\text { Length } \\
(\mathrm{mm})\end{array}$ & $\begin{array}{c}\text { Width } \\
(\mathrm{mm})\end{array}$ & $\begin{array}{c}\text { Thickness } \\
(\mathrm{mm})\end{array}$ & $\begin{array}{c}\text { Weight } \\
(\mathrm{g})\end{array}$ \\
\hline 1 & 7 & $50-60$ & 47.5 & 36.1 & 2.5 & 5.6 \\
1 & 7 & $50-60$ & 19.8 & 10.1 & 2.0 & 0.5 \\
1 & 9 & $\sim 110$ & 126.2 & 75.4 & 4.8 & 50.7 \\
1 & 9 & $\sim 110$ & 71.6 & 68.5 & 2.8 & 17.5 \\
1 & 9 & $\sim 110$ & 94.6 & 69.1 & 3.5 & 23.0 \\
2 & 5 & $40-50$ & 62.9 & 49.4 & 2.6 & 11.7 \\
\hline
\end{tabular}

\section{METHODS}

All specimens submitted for ${ }^{14} \mathrm{C}$ dating were recovered from the site in situ, cleaned of extraneous soil using distilled water, air dried, and individually bagged in airtight containers for transport. The pearl shell tool (OS-33447) and charcoal (OS-33568) sample were submitted to the National Oceanic Sciences Accelerator Mass Spectrometry (NOSAMS) facility at the Woods Hole Oceanographic Institution for AMS ${ }^{14} \mathrm{C}$ dating. Laboratory preparations were conducted using standard techniques, details of which can be found at the NOSAMS website <www.nosams.whoi.edu>. Three additional samples (two human bone [AA-40957, AA-43054] and one burned fishbone [AA43050]) were submitted to the NSF-University of Arizona AMS Facility. Pretreatment and analysis procedures for the bone are outlined in Fitzpatrick (2002a). All samples were calibrated at $1 \sigma$ using Calib 4.3 (Stuiver and Reimer 1993) ${ }^{3}$. A local $\Delta \mathrm{R}$ for shell in Palau has not yet been determined, so the mean global reservoir correction $\left(\sim 400{ }^{14} \mathrm{C}\right.$ yr) was used (Stuiver and Reimer 1993) ${ }^{4}$.

\footnotetext{
${ }^{2}$ See Fitzpatrick (2003) for a complete list of AMS dates from Chelechol ra Orrak to date, including those discussed here.

${ }^{3}$ Because the prehistoric diet is unknown but is presumed to contain both marine and terrestrial flora and fauna, the human bone samples were calibrated as 50\% marine and 50\% terrestrial to better reflect a mixed diet of shellfish, fish, and aroids (Hunter-Anderson 1991; Weisler 1999, 2000) common to the region. It should be noted that Ambrose et al. (1997) suggest marine protein consumption in the Mariana Islands (western Pacific) was around 20-50\% and would thus make human bone dates in Palau slightly older if recalibrated.

${ }^{4}$ See Kennett et al. (1997), Phelan (1999), Guilderson et al. (2000), Kuzmin et al. (2001), Yoneda et al. (2001), and Hideshima et al. (2001) for recent attempts to determine $\Delta \mathrm{R}$ correction values in other parts of the Pacific.
} 


\section{RADIOCARBON DATES}

${ }^{14} \mathrm{C}$ dates from the basal layers of Test Unit 1 revealed a range of human activity spanning over a 1000 -yr period from cal $970 \mathrm{BC}$ to AD 270 (Figure 2). The earliest date was cal $970-840 \mathrm{BC}$ from charcoal in Layer 8 (OS-33568). That this date was earlier than the others was not surprising considering the deposit was truncated by later burial episodes (Layer 9). The 4 bone and shell samples, all from Layer 9, dated from cal $770 \mathrm{BC}$ to $\mathrm{AD} 270$. The broad age range in this deposit can be attributed to one of the bone samples (AA-40957) dating to cal 770-550 BC; the other 3 dates fall within the range of cal AD 80-270. The earlier date in Layer 9 can probably best be explained as resulting from soil disturbance due to subsequent periods of burial activity (Fitzpatrick 2003). The later date of cal AD 150-270 obtained from the pearl shell scraper/grater lends support to this conclusion due to its direct association with the burial in Layer 9, as does the fragmentary nature of other skeletal remains recovered in Layers 7-9.

Figure 2 Stratigraphic profile from the east wall in Test Unit $1(\mathrm{~b}=$ human bone; $\mathrm{c}=$ charcoal; $\mathrm{f}=$ fishbone; $\mathrm{s}=$ shell scraper grater)

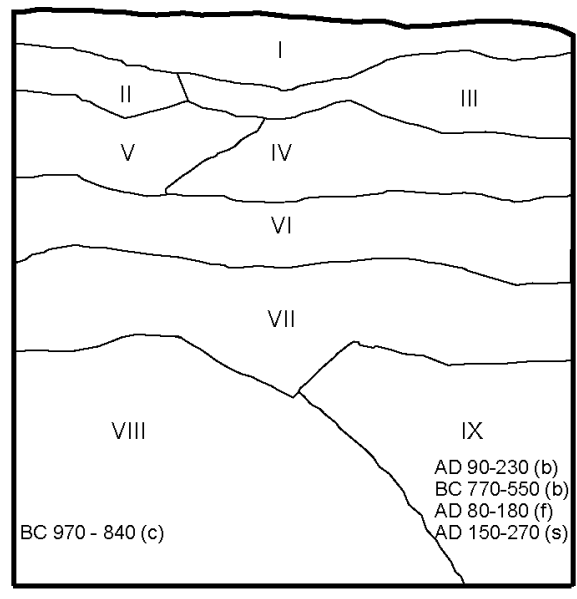

\section{PEARL SHELL ARTIFACTS}

Pearl shell is found in tropical or subtropical waters throughout the Indo- and western Pacific. Pinctada maxima (silver or golden-lipped pearl oyster), Pinctada margaritifera (black-lipped pearl oyster), and Pinctada radiata (Ceylon pearl oyster, also known as $P$. imbricata) are the most common species found in the western Pacific. P. maxima has a restricted range, commonly found around Australia's north coast, the Arafura Sea, and the Aru Islands in eastern Indonesia. It has a silver-yellow nacre with greenish tint and is the largest species, with lengths of up to $30 \mathrm{~cm}$. P. margaritifera's nacre is a rich silver gray with blue, green, or rose overtones edged with grayish-black and is slightly smaller with maximum lengths around $20 \mathrm{~cm}$. P. radiata are smaller, generally brownish with shades of red, and reach lengths ranging from 5 to $10.5 \mathrm{~cm}$ (sometimes misidentified as $P$. margaritifera; Dance 1974; Wye 1991). Pinctada sp. typically attach themselves to hard substrata (e.g. under stones, in crevices of rocks) in intertidal and subtidal environments at depths ranging from very shallow to 190+ $m$ in depth. Today, all 3 species are prized for their pearls and commercially cultivated.

Judging from the size and coloration of the pearl shell scrapter/grater tools from Chelechol ra Orrak and comparative specimens from Ngermereues Ridge (Rieth and Liston 2001), they appear to be made from P. margaritifera (Linnaeus 1758). The artifacts exhibit no external lamellae that would prove more useful in identifying the particular species. However, nearly all other pearl shell refuse found at the site have a grayish-green exterior, typical of $P$. margaretifera. 
This tool type appears to be rare in Micronesia. Somewhat surprisingly, a review of the literature reveals only 1 other example of these tools found in archaeological sites in the region, also from Palau (Rieth and Liston 2001:44-8), despite pearl shell having been used throughout Micronesia for producing other objects. The artifacts found associated with the burial in Test Unit 1 at Chelechol ra Orrak range from $6.9 \mathrm{~cm}$ to $7.5 \mathrm{~cm}$ in width and 7.2 to $12.6 \mathrm{~cm}$ in length. All 3 are roughly halfmoon in shape and retain the natural curvature of the shell (Figure 3). Serrations are present on one side of each tool to create a grating or scraping edge useful for peeling vegetables, grating coconut, or some other cutting function (Figure 4).

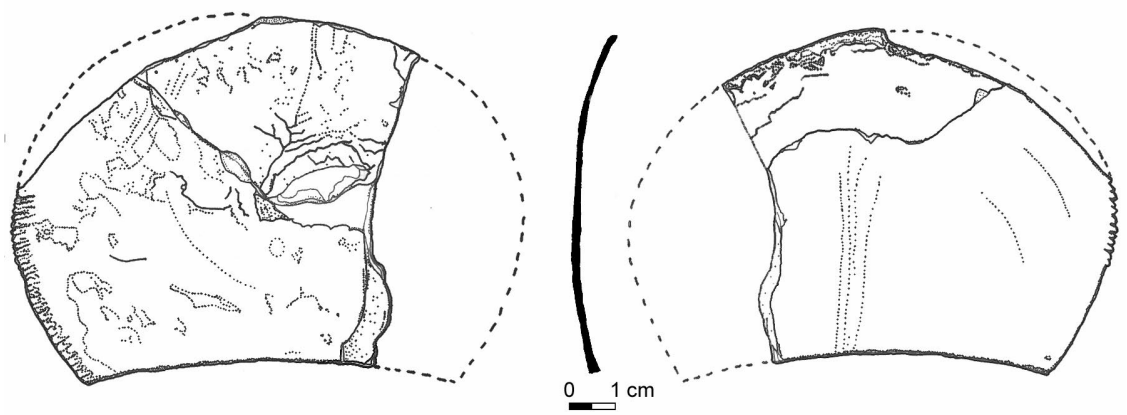

Figure 3 Pearl shell scraper/grater (drafted by Jenna Boyle)

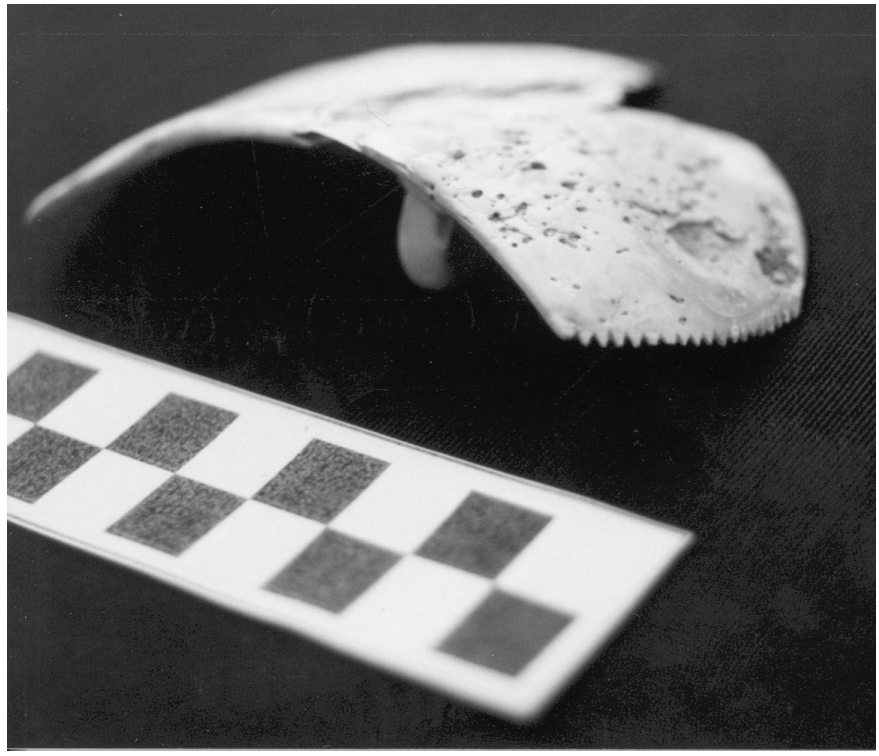

Figure 4 Photo of the serrated edge from a pearl shell scraper/grater (photo courtesy of Brian D Diveley)

\section{DISCUSSION}

${ }^{14} \mathrm{C}$ dates indicate that pearl shell grater/scraper tools were used at least $2000 \mathrm{yr}$ ago as burial goods at Ngermereues Ridge (Rieth and Liston 2001) and Chelechol ra Orrak. They are similar to ones described as coconut graters in early ethnohistoric accounts (Adams et al. 1997), suggesting these 
artifacts have a long antiquity in Palau. Rieth and Liston (2001) did not directly date any of these tools, but ${ }^{14} \mathrm{C}$ dates of human bone from burial chambers dated from cal $470 \mathrm{BC}$ to $\mathrm{AD} 780(2 \sigma)$ and are within the range of the pearl shell artifacts from Chelechol ra Orrak.

Rieth and Liston (2001:49) note that "[t]he association of marine shell with the burials most likely represents the need to supply the soul with subsistence and tools to carry with them on their journey to the afterlife." Although this is speculative, the question remains as to what role these tools played in Palauan social systems, since grave goods are often indicators of an individual's gender, status, or occupation (Pearson 2000).

In ethnographic references (Adams et al. 1997:49), pearl shell is listed as a form of women's money (chesiuch) and often associated with female tasks such as grating taro or coconut. These tools were also apparently added along with food to a basket prepared for pregnant women by their parents as part of the birth ritual (Adams et al. 1997:31). Of the 6 pearl shell scraper/graters found by Rieth and Liston (2001), 3 were associated with a single individual from Chamber 7A, 2 with individuals in Chamber 4 (MNI=4), and 1 with an individual from Chamber 9 (Rieth and Liston 2001:71). Although sexing of the skeletons was difficult and could not be determined for most of the assemblage, Rieth and Liston (2001:31) report that at least 1 of the burials from Chamber 4 may be female. The Layer 9 burial at Chelechol ra Orrak is also female, suggesting the distribution of these particular pearl shell tools may be indicative of gender and status.

This research is the first direct dating of a pearl shell scraper/grater tool in Palau, a rare documented use of Pinctada sp. shell for this artifact type in Micronesia. AMS ${ }^{14} \mathrm{C}$ dating of shell artifact, bone, and charcoal samples from burial deposits at Chelechol ra Orrak indicates that burial activity at the site began around $3000 \mathrm{yr} \mathrm{ago}$, with pearl shell scraper/graters used as grave goods roughly $1000 \mathrm{yr}$ later. The interment of these tools with female burials is indicative of the high status some women attained in early Palauan society. This also supports ethnohistoric and ethnographic accounts stating that pearl shell was a gender and probably a status marker used almost exclusively by women for processing coconuts and starchy root crops like taro (Colocasia sp.) and giant swamp taro (Cyrtosperma sp.). Additional fieldwork in western Micronesia is expected to supply a greater variety of pearl shell artifacts in which better comparisons can be made with those found in other parts of Oceania. Our data support the findings by other researchers suggesting that directly dating artifacts using AMS is a critical step for developing and refining artifact chronologies, especially in sites with complex stratigraphic relationships.

\section{ACKNOWLEDGMENTS}

Funding for this and related research was provided by the National Science Foundation (SBR0001531), a Sasakawa Graduate Fellowship (Fitzpatrick), and a Sasakawa Peace Foundation training initiative awarded to William S Ayres as part of a Micronesian cooperative archaeological field training project between the University of Oregon and Palau Bureau of Arts and Culture (BAC). Funding for AMS ${ }^{14} \mathrm{C}$ dates was enhanced by NSF sponsorship and cooperative agreements with NOSAMS (OCE-9807266) and the NSF-University of Arizona AMS Facility. We are particularly thankful to the Palau BAC staff for their continued support over the years and help in excavating and cataloging a portion of the archaeological assemblage. William S Ayres, Christophe Descantes, Jon Erlandson, Douglas J Kennett, and Torben Rick commented on drafts of this manuscript and/or discussed with us specimen selection criteria for ${ }^{14} \mathrm{C}$ dating. We also thank Patrick V Kirch for his review of the paper. Greg C Nelson (University of Oregon) analyzed the skeletal assemblage. The editors of the journal, particularly Kimberley T Elliott, were extremely helpful in preparing this manuscript for publication. 


\section{ARCHAEOLOGICAL SAMPLES}

\section{OS-33447. Chelechol ra Orrak}

$2140 \pm 50$

$\delta^{13} \mathrm{C}=0.36 \%$

This determination was obtained from a fragment of a pearl shell (Pinctada sp.) scraper/grater $(1.6 \mathrm{~g})$ tool recovered from Test Unit 1, Layer 9, at a depth of 100-110 cmbs. The artifact was one of three found directly above the left femur of burial 1. Calibrated date range at $1 \sigma:$ AD 150-270.

\section{OS-33568. Chelechol ra Orrak}

$2770 \pm 30$

$\delta^{13} \mathrm{C}=-25.9 \%$

This determination was obtained from wood charcoal $(0.1 \mathrm{~g})$ recovered from Test Unit 1 , Layer 8 , at a depth of 100-110 cmbs. Calibrated date range at 1 $\sigma: 970-840 \mathrm{BC}$.

\section{AA-40957. Chelechol ra Orrak}

$2680 \pm 40$

$\delta^{13} \mathrm{C}=-15.7 \%$

This determination was obtained from a human cranial bone fragment $(3.0 \mathrm{~g})$ recovered from Test Unit 1, Layer 9, at a depth of 90-100 cmbs. Calibrated date ranges at 1 $\sigma: 890-800 \mathrm{BC}$ (100\% terrestrial) and 770-550 BC (50\% marine and 50\% terrestrial).

\section{AA-43050. Chelechol ra Orrak}

$2220 \pm 40$

$\delta^{13} \mathrm{C}=-12.6 \%$

This determination was obtained from an unidentified burned fish bone (1.1 g; probably pelagic) recovered in Test Unit 1, Layer 9, 100-110 cmbs. Calibrated date range at $1 \sigma$ : AD 80 (130) 180. Petchey and Higham (2000) suggest that reliable ${ }^{14} \mathrm{C}$ dating of fish bone (barracouta - Thyrsites atun) may be accomplished if the reservoir conditions of fish are similar to those of locally collected shellfish. This, however, has not been tested in Palau.

\section{AA-43054. Chelechol ra Orrak}

$2030 \pm 40$

$\delta^{13} \mathrm{C}=-15.4 \%$

This determination was obtained from a human left navicular bone fragment $(0.8 \mathrm{~g})$ from Test Unit 1, Layer 9, 80-90 cmbs. Calibrated date range at $1 \sigma: 90$ BC-AD 50 (100\% terrestrial) and AD 90 (140) 230 (50\% marine and 50\% terrestrial).

\section{REFERENCES}

Adams WH, Gibbons F, Smith DR. 1997. Palau ethnography. Micronesian Endowment for Historic Preservation, Republic of Palau. San Francisco: U.S. National Park Service.

Allen MS. 1994. Style and function in East Polynesian fish-hooks. Antiquity 70:97-116.

Ambrose SH, Butler BM, Hanson DB, Hunter-Anderson RL, Krueger HW. 1997. Stable isotopic analysis of human diet in the Marianas archipelago, western Pacific. American Journal of Physical Anthropology 104:34361

Athens JS, Ward JV. 2001. Paleoenvironmental evidence for early human settlement in Palau: the Ngerchau core. In: Lee G, editor. Pacific 2000 Conference Proceedings. Los Osos: Easter Island Foundation. p 165-78.
Ayres WS. 1990. Pohnpei's position in eastern Micronesian prehistory. Micronesica, Supplement 2:187-212. Beardsley FR. 1998. Sngall Ridge, Belau: burials, spirit walks, and painted pottery. Paper presented at the 16 th Congress of the Indo-Pacific Prehistory Association, Melaka, Malaysia, 1-7 July 1998.

Bellwood P. 1978. Archaeological research in the Cook Islands. B. P. Bishop Museum. Pacific Anthropological Records 27.

Blaiyok V. 1993. Archaeological Survey of Airai State, Republic of Palau. Report submitted to the Division of Cultural Affairs, Koror, Palau.

Carucci J. 1992. Cultural and natural patterning in prehistoric marine foodshell from Palau, Micronesia. $\mathrm{PhD}$ thesis. Southern Illinois University, Carbondale, 
USA.

Dance P. 1974. The collector's encyclopedia of shells. New York: McGraw-Hill.

Davidson JM. 1968. Nukuoro-Archaeology on a Polynesian outlier in Micronesia. In Yawata I, Sinoto YH, editors. Prehistoric culture in Oceania. Honolulu: Bishop Museum Press. p 51-66.

Emory KP. 1975. Material culture of the Tuamotu archipelago. Pacific Anthropological Records No. 22. Honolulu: Bernice P. Bishop Museum.

Emory KP, Bonk WJ, Sinoto Y. 1959. Hawaiian archaeology: fishhooks. Honolulu: B.P. Bishop Museum Special Publication 47.

Fitzpatrick SM. 2001. Archaeological investigation of Omis Cave: a Yapese stone money quarry in Palau. Archaeology in Oceania 36:153-62.

Fitzpatrick SM. 2002a. AMS dating of human bone in Palau: new evidence for a pre-2000 BP settlement. $R a$ diocarbon 44(1):217-21.

Fitzpatrick SM. Forthcoming. A radiocarbon chronology of Yapese stone money quarries in Palau. Micronesica.

Fitzpatrick SM. Forthcoming. Early human burials at Chelechol ra Orrak: evidence for a 3000 year old occupation in western Micronesia. Antiquity.

Guilderson TP, Schrag DP, Goddard E, Kashgarian M, Wellington GM, Linsley BK. 2000. Southwest subtropical Pacific surface water radiocarbon in a highresolution coral record. Radiocarbon 42(2):249-56.

Hideshima S, Matsumoto E, Abe O, Kitigawa H. 2001. Northwest Pacific marine reservoir correction estimated from annually banded coral from Ishigaki Island, southern Japan. Radiocarbon 43(2A):473-6.

Hunter-Anderson RL. 1991. A review of traditional Micronesian high island horticulture in Belau, Yap, Chuuk, Pohnpei, and Kosrae. Micronesica 24:1-56.

Intoh M. 1998. The catalogue of prehistoric Micronesian artifacts housed in Japan. Saipan: Micronesian Archaeological Survey Report Number 34.

Intoh M, Leach F. 1985. Archaeological investigations in the Yap Islands, Micronesia: first millennium B.C. to the present day. Oxford: British Archaeological Reports 277.

Kennett DJ, Ingram BL, Erlandson JM, Walker P. 1997. Evidence for temporal fluctuations in marine radiocarbon reservoir ages in the Santa Barbara Channel, southern California. Journal of Archaeological Science 24:1051-9.

Kirch PV. 1997. The Lapita peoples: ancestors of the oceanic world. Oxford: Blackwell Publishers.

Kirch PV. 1979. Marine exploitation in prehistoric Hawai'i: archaeological investigations at Kalahuipua'a, Hawai'i Island. Honolulu: Pacific Anthropological Records 29.

Kirch PV, Flenley JR, Steadman DW, Lamont F, Dawson S. 1992. Ancient environmental degradation. Prehistoric human impacts on an island ecosystem: Mangaia, central Polynesia. National Geographic Re- search and Exploration 8:166-79.

Kuzmin YV, Burr GS, Jull AJT. 2001. Radiocarbon reservoir correction ages in the Peter the Great Gulf, Sea of Japan, and eastern coast of the Kunashir, southern Kuriles (northwestern Pacific). Radiocarbon 43(2A): 477-81.

Liston J, Mangieri TM, Grant D, Kaschko MW, Tuggle HD. 1998. Archaeological data recovery for the compact road, Babeldaob Island, Republic of Palau. Historic preservation investigations phase II. Volume II: Fieldwork reports. Honolulu: International Archaeological Research Institute.

McGovern-Wilson R, Quinn C. 1996. Stable isotope analysis of ten individuals from Afetna, Saipan, Northern Mariana Islands. Journal of Archaeological Science 23:59-5.

Nelson, GC, Fitzpatrick SM, McGlaughlin J. 2002. A bioarchaeological investigation of a $2700 \mathrm{BP}$ cemetery in the Republic of Palau, Micronesia (abstract). Paper presented at the American Physical Anthropology Meetings. American Journal of Physical Anthropology Supplement 34:117.

Pearson MP. 2000. Archaeology of death and burial. College Station: Texas A\&M University Press.

Petchey F, Higham T. 2000. Bone diagenesis and radiocarbon dating of fish bones at the Shag River Mouth site, New Zealand. Journal of Archaeological Science 27:135-50.

Phelan MB. 1999 A $\Delta$ R correction value for Samoa from known-age marine shells. Radiocarbon 41(1):99-101.

Rick T. 2001. AMS radiocarbon dating of a shell fishhook from Santa Rosa Island, California. Radiocarbon 43(1):83-6.

Rieth TM, Liston J. 2001. Archaeological data recovery at Ngermereues Ridge, Ngesaol, Koror, Republic of Palau. Honolulu: International Archaeological Research Institute.

Shun K, Athens JS. 1990. Archaeological investigations on Kwajalein Atoll, Marshall Islands, Micronesia. Micronesica Supplement 2: 231-40.

Sillitoe P. 1988. Made in Niugini: technology in the highlands of Papua New Guinea. London: British Museum Publications Ltd.

Sinoto YH. 1968. Position of the Marquesas Islands in east Polynesian prehistory. In: Yawata I, Sinoto YH, editors. Prehistoric culture in Oceania. Honolulu: Bishop Museum Press. p 111-8.

Sinoto Y. 1984. Descriptions of portable artifacts (other than pottery) from Fefan Island. In: Sinoto YH, editor. Caroline Islands archaeology: investigations on $\mathrm{Fe}$ fan, Faraulep, Woleai, and Lamotrek. Honolulu: Pacific Anthropological Records No. 5. p 26-38.

Sinoto YH, McCoy PC. 1974. Archaeology of Teti' aroa atoll, Society Islands. Report 74-2. Honolulu: Bernice P. Bishop Museum.

Speiser F. 1990. Ethnology of Vanuatu: an early twentieth century study. Bathurst: Crawford House Press. 
Stuiver M, Reimer P. 1993. Extended ${ }^{14} \mathrm{C}$ database and revised CALIB $3.0{ }^{14} \mathrm{C}$ age calibration program. $R a$ diocarbon 35(1):215-30.

Vellanoweth R. 2001. AMS radiocarbon dating and shell bead chronologies: middle holocene trade and interaction in western North America. Journal of Archaeological Science 28:941-50.

Walter R. 1989. An archaeological fishhook assemblage from the southern Cook Islands. Man and Culture in Oceania 5:67-77.

Walter R. 1990. The southern Cook Islands in eastern Polynesian prehistory. PhD thesis. Auckland: University of Auckland, New Zealand.

Weisler MI. 1999. The antiquity of aroid pit agriculture and significance of buried A horizons on Pacific atolls. Geoarchaeology 14:621-54.
Weisler MI. 2000. Burial artifacts from the Marshall Islands: description, dating, and evidence for extra-archipelago contacts. Micronesica 33(1/2):111-36.

Wickler S. 2001. The colonization of western Micronesia and early settlement in Palau. In: Lee G, editor. Pacific 2000 Conference Proceedings. Los Osos: Easter Island Foundation. p 185-96.

Wickler S. 2001. The prehistory of Buka: a stepping stone island in the northern Solomons. Terra Australis 16. Canberra: Australian National University.

Wye K. 1991. The encyclopedia of shells. London: Chartwell Books.

Yoneda M, Hirota M, Uchida M, Uzawa K, Tanaka A, Shibata Y, Morita M. 2001. Marine radiocarbon reservoir effect in the western north Pacific observed in archaeological fauna. Radiocarbon 43(2A):465-71. 